\title{
Examination of Association between Mobile Phone Usage and Daytime Sleepiness in Delhi Millennial
}

Effulgence

Vol. 16 No. 1 (Special Issue 2)

January - June, 2018 Rukmini Devi Institute of Advanced Studies

E-mail : effulgence@rdias.ac.in, Website : www.rdias.ac.in

http://effulgence.rdias.ac.in/user/default.aspx

https://dx.doi.org/10.33601/effulgence.rdias/v16/iSpl2/2018/54-64

\section{Ms. Tanvi Gupta ${ }^{1}$}

\begin{abstract}
Purpose: Mobile usage is an indispensable activity for the youth nowadays. Its excessive usage can lead to certain unwelcomed consequences. Amongst some of such problems is daytime sleepiness in youth studying in schools and colleges or at workplace due to incessant usage of mobile phones, especially at night. Epworth Sleepiness Scale (ESS) is a renowned scale firstly proposed by Dr. Johns and further modified to study the daytime sleepiness for human race. This study aims at examining the relationship between the mobile usage habits of youth studying at a B-school in Delhi and their ESS scores.

Design/methodology: It is a descriptive research which has been conducted using an adapted questionnaire used by Nathan, N. and Zeitzer, J. to study the association between mobile phone usage and daytime sleepiness in students in a Californian high school. In the current study, convenience sampling has been used by distributing the questionnaires to students at a management college in Delhi. The sample size taken is 113. A pre-test was conducted on 20 students giving Cronbach's alpha $=.798$ making the questionnaire reliable. Also, face validity and content validity was tested by academicians. Descriptive analysis including frequency was used for demographical factors and ESS scores. Descriptives were further provided as the mean $\square \pm \square S D$ for age and for number of text messaged and/or the phone calls made or received on daily basis. For inferential analysis, Pearson's coefficient of correlation and multiple regressions were used to test the degree of association between ESS and the independent variables (mobile usage).

Limitations: Resource limitation is an unavoidable factor. It being a sample study concerned with one college can be replicated as a census study covering more colleges.

Findings/implications: Multivariate regression analysis indicated that ESS was significantly associated with the average number of call per day and the expectation of being accessible via mobile phones. The findings threw light on the association between the mobile (disruptive technology) usage behaviour and daytime sleepiness amongst the students at the stipulated management college in Delhi. It would be helpful in assessing the impact of the disruptive technology on students and hence, measures can be devised to curb those factors. Further scope of research is created to fill the gaps of current research.
\end{abstract}

Keywords: Epworth Sleepiness Scale, mobile usage, demographical factors, multiple regressions, disruptive technology.

1. Assistant Professor, Jagannath International Management School, Kalkaji, New Delhi, tanvi.gupta@jagannath.org 


\section{INTRODUCTION}

pworth Sleepiness Scale (ESS) was first
developed by Dr. Johns during his research on "daytime sleepiness" amongst his patients for developing sleep medicine. He named this scale after Epworth Hospital in Melbourne where he had established his sleep center. This scale was developed in the year 1990 and was further refined in the year $1997^{1}$. ESS questionnaire aims at obtaining ratings on a 4-point Likert scale (0-3) from the respondents of their usual chances of dozing off or having fallen asleep when engaged in 8 different activities; sitting and reading, watching TV, sitting inactively at a public place, as a passenger in a vehicle for an hour without break, lying down to rest in the noon, sitting and talking to someone, sitting after lunch without any alcohol and sitting in car that has stopped in traffic for a while (Johns, 2002). The responses on these activities are summated to obtain the score on ESS. The normal score ranges from 2-10 whereas scores from 11-24 imply increasing level of excessive daytime sleepiness (EDS) (Johns and Hocking, 1997; Sanford et al, 2006).

Mobile phones are no more a luxury but a necessity for Indian youth. The predictions made in the last decade by industry researchers and corporate heads are all falling in line with the increasing usage of mobile phone amongst the millennial. Sandip Das, Head, Orange phones in Mumbai stated that the population under 25 years is in majority in India and is tech savvy. Also, Sunil Sinha, a consultant at National Council for Applied Economic Research documented young Indians to create huge market for services and mobiles being one of them. ${ }^{2}$

According to a study conducted by the global research firm, TNS, it was examined that in India, millennial spend almost 2.2 hours per day on mobile driven digital access. ${ }^{3}$ Young population is found to spend maximum time on chatting (wtsuping) followed by listening to music, internet browsing, entertainment purposes etc. (Akanferi, Aziale and Asampana, 2014). About $70 \%$ of the urban youth in India owns a mobile phone (Bamzai, 2007). Infact, Telecom Regulatory Authority of India (TRAI) has claimed that mobile phone is the only way that connects more than half the Indian population (TRAI, 2008-09). Empirical research regarding mobile phones needs attention in India as it is the world's largest democracy with billions of people living here and mobile phone usage being popular amongst the youth (CIA, 2009). Also, mobile phone characteristics including texting, etc. are related to sleep disturbances (Gold, J.E., et al, 2015). Various studies have shown that mostly adolescents use mobile phones and suffer from sleep deprivation (Nehra, R, et al, 2012).

Considering, the wide usage of mobile phones by Indian youth, this study aims at studying the relationship between mobile usage by Generation Y (born between 1980 and 1990) and the daytime sleepiness on Epworth sleepiness scale.

\section{Literature review}

Kawada, T., et al (2017) investigated the relationship between the usage of mobile phones and diurnal type scale and sleep habit among the students aged 18-30 years in Japan. A cross-sectional study was carried using self- administered questionnaire on a sample size of 531 university students. It was found that most of the students had their own mobile phones. Around half the respondents admitted using phone within 30minutes duration per usage and 180 students used it 5-6 hours per usage. There was no significant difference observed in the diurnal type scale scores due to the durations of usage per usage. Tamura, H., et al (2017) conducted another research

1. http:/ / epworthsleepinessscale.com/about-the-ess/

2. Dhillon Amrit (April 20, 2004), Indian Youth at the wheel in drive for cultural change, The Observer, New Delhi.

3. https://www.nextbigwhat.com/india-youth-mobile-usage-297/ 
in Japan to study the relationship between mobile phone use and insomnia and depression in adolescents. Out of the 295 students surveyed, 58.6\% of them were found to use phone for 2 hours per day and $10.5 \%$ used it for over 5 hours per day. Use of mobile for over 5 hours/day was associated with insomnia but not depression.

Nasirudeen, A., et al (2017) conducted an empirical study to examine the relationship between social media usage and daytime sleepiness in tertiary students in Singapore using a cross sectional, quantitative research design. It was found that most common means to use social media was smartphones. Singapore students spent more time on social media than foreign students and thus, experienced more day time sleepiness. Deepali, A., et al (2015) observed that increased mobile usage in medical students aggravated their daytime sleepiness.

Nathan, N., \& Zeitzer, J. (2013) studied the relationship between nocturnal usage of mobile phones and daytime sleepiness in the high school students in California using Epworth Sleepiness Scale (ESS). Regression analysis of the data proved that ESS was associated significantly with female, need to be accessible over mobile phone all the time and the past attempt to reduce the usage. Troxel, W.M. (2015) focused on studying the texting behaviour of teens and found that texting was very much prevalent at night with $70 \%$ of the respondents admitted doing it. Patel, A. \& Rathod, H. (2011).also documented through a primary research that most of the student respondents in rural Gujarat used phones during evenings. Subba, S.H., et al (2013) found ringxiety associated with increased mobile usage in medical students in South India.

Carter, B., et al (2016), through the meta analysis of 467 previous studies to investigate the effects of portable media devices on the sleep outcomes of kids revealed that nocturnal use of mobile phones was significantly related to the excessive daytime sleepiness. (Hale, L., \& Guan, S., 2015) also systematically reviewed scientific literature to examine the relationship between time spent onscreen and sleep outcomes on school kids and adolescents which revealed that they are adversely related as per $90 \%$ of the studies.

Previous research regarding mobile usage and daytime sleepiness has been conducted for various countries, majorly outside India. Most of the studies have taken respondent base as the students in high schools or medical students. Despite the growing number of young individuals, limited examination has been done in the stipulated context in urban India. Considering, these research gaps, the current study aims at studying the association between mobile phone usage and daytime sleepiness using ESS among the Generation Y in urban India.

\section{Research methodology}

Obj.1: To examine the relationship between number of calls and sleepiness (ESS).

Obj.2: To examine the relationship between number of text messages and sleepiness (ESS).

Obj.3: To examine the relationship between frequency of being awakened by mobile at night and sleepiness (ESS).

Obj.4: To examine the relationship between staying up late for mobile usage and sleepiness (ESS).

Obj.5: To examine the relationship between accessibility via mobile phone and sleepiness (ESS).

Obj.6: To examine the relationship between stress due to mobile phones and sleepiness (ESS).

Obj.7: To examine the relationship between excess mobile usage and sleepiness (ESS).

Obj.8: To examine the relationship between failed attempt to cut down mobile usage and sleepiness (ESS).

HO1: Sleepiness is positively related to the number of calls made/received per day.

HO2: Sleepiness is positively related to the number of text messages sent/received per day.

HO3: Sleepiness is positively related to the frequency of being awakened by mobile at night.

HO4: Sleepiness is positively related to staying up 
late for mobile usage.

Ho5: Sleepiness is positively related to accessibility via mobile phone.

HO6: Sleepiness is positively related to stress due to mobile phones.

HO7: Sleepiness is positively related to excess mobile usage.

HO8: Sleepiness is positively related to failed attempt to cut down mobile usage.

Following a literature review exploratory research design, this research continues as a descriptive research. The target population has been taken from a management college affiliated to Guru Gobind Singh Indraprastha University, Delhi based on convenience sampling. The sample size taken is 113 . An adapted questionnaire ${ }^{1}$ with some modification has been used which was previously used to investigate association between mobile usage and daytime sleepiness amongst teenagers in California high school. A pre-test was also conducted using this questionnaire on 20 students at JIMS, Kalkaji, New Delhi. Cronbach's alpha was 0.798 making it reliable. Face and content validity was also tested by academicians and experts in this area. SPSS 20 has been used as the analysis software. Descriptive analysis has been done using means, frequencies and cross-tabs. Inferential analysis has been done using multiple regressions in order to test the hypothesis.

\section{Data analysis and interpretation}

Table 1 describes the composition of the sample with average age being 20.16 years and comprising of $69.03 \%$ as males and $30.07 \%$ as females. The degree of association of average number of calls and text messages per day has been found to be significant as eta squared is less than 0.05 .

Table 1: Descriptive analysis of demographic variables

\begin{tabular}{|l|l|l|l|l|l|l|}
\hline $\begin{array}{l}\text { Age } \\
\text { (Mean } \\
\pm \text { S.D. }\end{array}$ & Gender & N & $\begin{array}{l}\text { Average calls } \\
\text { made/received } \\
\text { per day (Mean } \\
\pm \text { S.D.) }\end{array}$ & $\begin{array}{l}\text { Eta squared } \\
\text { (Calls*gender) }\end{array}$ & $\begin{array}{l}\text { Average text } \\
\text { messages } \\
\text { made/received } \\
\text { per day (Mean } \\
\pm \text { S.D.) }\end{array}$ & $\begin{array}{l}\text { Eta squared } \\
\text { (Texts*gender) }\end{array}$ \\
\hline $\begin{array}{l}20.16 \pm \\
.91\end{array}$ & $\begin{array}{l}\text { Male } \\
\text { Female }\end{array}$ & 78 & $\begin{array}{l}10.10 \pm 9.10 \\
295.06 \pm 1688.70\end{array}$ & 0.02 & $\begin{array}{l}96.97 \pm 277.03 \\
101.77 \pm 208.98\end{array}$ & 0.001 \\
\hline
\end{tabular}

Table 2 represents the descriptive analysis for Epworth Sleepiness Scale score and other variables of mobile usage in terms of their means and standard deviations.

Table 2: Descriptive analysis of Part-a and $b$.

\begin{tabular}{|l|c|c|}
\hline & Mean & Std. Deviation \\
\hline Epworth Sleepiness Scale score & 6.7080 & 2.94801 \\
\hline Average calls made/received per day & 98.36 & 939.829 \\
\hline Average text messages made/received per day & 98.46 & 256.957 \\
\hline $\begin{array}{l}\text { How often have you been awakened by your } \\
\text { mobile phone? }\end{array}$ & 1.54 & 1.310 \\
\hline
\end{tabular}

1. Nathan, N. \& Zeitzer, J. (2013), A survey study of the association between mobile phone use and daytime sleepiness in California high school students, BMC Public Health, 13, pp. 840. 


\begin{tabular}{|l|c|c|}
\hline $\begin{array}{l}\text { How often have you stayed up late than you } \\
\text { wanted because of mobile? }\end{array}$ & 1.96 & 1.420 \\
\hline $\begin{array}{l}\text { To what extent are you expected by those } \\
\text { around to be accessible via mobile? }\end{array}$ & 2.08 & .918 \\
\hline $\begin{array}{l}\text { To what extent you feel accessibility via } \\
\text { mobile phones stressful? }\end{array}$ & .84 & .676 \\
\hline $\begin{array}{l}\text { Do you or someone around you feels you use } \\
\text { the mobile too much? }\end{array}$ & 1.30 & .461 \\
\hline $\begin{array}{l}\text { Have you tried but failed, to cut down mobile } \\
\text { use? }\end{array}$ & 1.50 & .520 \\
\hline
\end{tabular}

Table 3 has documented that maximum number of students depicted "Higher Normal Daytime Sleepiness" (52.2\%) followed by Lower Normal sleepiness $(36.3 \%)$, then mild excessive $(8.8 \%)$ and the least represented moderate excessive sleepiness
(2.7\%). None showed secure excessive daytime sleepiness. ESS score between $0-10$ is considered normal and beyond 11 can bring concerns if left unchecked.

Table 3 : Frequency (\%) analysis of the Epworth Sleepiness Scale score

\begin{tabular}{|l|l|c|c|}
\hline Range of ESS score & Interpretation & Frequency (N) & Percentage (\%) \\
\hline $0-5$ & $\begin{array}{l}\text { Lower Normal Daytime } \\
\text { Sleepiness }\end{array}$ & 41 & 36.3 \\
\hline $6-10$ & $\begin{array}{l}\text { Higher Normal Daytime } \\
\text { Sleepiness }\end{array}$ & 59 & 52.2 \\
\hline $11-12$ & $\begin{array}{l}\text { Mild Excessive Daytime } \\
\text { Sleepiness }\end{array}$ & 10 & 8.8 \\
\hline $13-15$ & $\begin{array}{l}\text { Moderate Excessive } \\
\text { Daytime Sleepiness }\end{array}$ & 3 & 0 \\
\hline $16-24$ & $\begin{array}{l}\text { Secure Excessive Daytime } \\
\text { Sleepiness }\end{array}$ & 0 & 2.7 \\
\hline
\end{tabular}

Table 4 represents the Pearson's coefficient and level of significance between the ESS score and the mobile usage variables (IV) depicted as A, B, C, D, E, F, G and $\mathrm{H}$. Correlation between ESS score and average number of calls made/received per day was found to be positive with value .233. On further using the statistical test procedure, the significance value since is lower than $.05(p<.05)$, it indicates correlation is significant at $5 \%$ level. Similarly, correlation between ESS and expectation of others for the student being accessible via phone was positive with value 180 . Since, $\mathrm{p}<.05$, thus, this correlation is statistically significant at $5 \%$ level. For all other independent variable, $\mathrm{p}>0.05$, thus no statistically significant relationship is observed.

The R-square value as shown in Table 5 is an accepted value for behavioral sciences analysis as it is between .10-.20. In social sciences research, a value between (.10-.20) of R square is acceptable (Gaur A.S. \& Gaur, S.S, 2012). 
Table 4 : Correlation for ESS scores with independent variables or predictors: A, B, C, D, E, F, G and H.

Pearson's Correlation

\begin{tabular}{|c|c|c|c|c|c|c|c|c|c|}
\hline & $\begin{array}{c}\text { Epwor } \\
\text { th } \\
\text { Sleepi } \\
\text { ness } \\
\text { Scale } \\
\text { (ESS) }\end{array}$ & $\begin{array}{l}\text { Average } \\
\text { calls } \\
\text { made/rec } \\
\text { eived per } \\
\text { day (A) }\end{array}$ & $\begin{array}{c}\text { Text } \\
\text { messages } \\
\text { made/rec } \\
\text { eived per } \\
\text { day }(\mathrm{B})\end{array}$ & $\begin{array}{c}\text { How } \\
\text { often } \\
\text { have } \\
\text { you } \\
\text { been } \\
\text { awake } \\
\text { ned by } \\
\text { your } \\
\text { mobil } \\
\text { e } \\
\text { phone } \\
?(\mathrm{C})\end{array}$ & $\begin{array}{l}\text { How } \\
\text { often } \\
\text { have } \\
\text { you } \\
\text { staye } \\
\text { d up } \\
\text { late } \\
\text { than } \\
\text { you } \\
\text { want } \\
\text { ed } \\
\text { beca } \\
\text { use } \\
\text { of } \\
\text { mobi } \\
\text { le? } \\
\text { (D) }\end{array}$ & $\begin{array}{c}\text { To } \\
\text { what } \\
\text { extent } \\
\text { are } \\
\text { you } \\
\text { expect } \\
\text { ed by } \\
\text { those } \\
\text { around } \\
\text { to be } \\
\text { access } \\
\text { ible } \\
\text { via } \\
\text { mobile } \\
\text { ? (E) }\end{array}$ & $\begin{array}{l}\text { To what } \\
\text { extent } \\
\text { you feel } \\
\text { accessib } \\
\text { ility via } \\
\text { mobile } \\
\text { phones } \\
\text { stressful } \\
?(\mathrm{~F})\end{array}$ & $\begin{array}{l}\text { Do } \\
\text { you } \\
\text { or } \\
\text { some } \\
\text { one } \\
\text { aroun } \\
\text { d you } \\
\text { feels } \\
\text { you } \\
\text { use } \\
\text { the } \\
\text { mobil } \\
\text { e too } \\
\text { much } \\
\text { ? (G) }\end{array}$ & $\begin{array}{c}\text { Hav } \\
\text { e } \\
\text { you } \\
\text { tried } \\
\text { but } \\
\text { faile } \\
\text { d, to } \\
\text { cut } \\
\text { dow } \\
\text { n } \\
\text { mob } \\
\text { ile } \\
\text { use? } \\
\text { (H) }\end{array}$ \\
\hline $\begin{array}{l}\text { ESS- } \\
\text { Pearson's } \\
\text { coefficien } \\
\text { t (r) }\end{array}$ & 1.000 & .233 & -.021 & .111 & .119 & .180 & .035 & -.040 & $\begin{array}{c}- \\
.049\end{array}$ \\
\hline $\begin{array}{l}\text { Significan } \\
\text { ce( } 1- \\
\text { tailed)(p) }\end{array}$ & & .006 & .412 & .122 & .105 & .028 & .358 & .337 & .304 \\
\hline $\begin{array}{l}\text { (A) } \\
\text { Pearson's } \\
\text { coefficien } \\
t(r)\end{array}$ & .233 & 1.000 & .335 & -.109 & .005 & -.111 & .023 & -.062 & .092 \\
\hline $\begin{array}{l}\text { Significan } \\
\text { ce( } 1- \\
\text { tailed })(p)\end{array}$ & .006 & & .000 & .126 & .481 & .120 & .403 & .258 & .167 \\
\hline $\begin{array}{l}\text { (B) } \\
\text { Pearson's } \\
\text { coefficien } \\
\text { t (r) }\end{array}$ & .111 & -.109 & .089 & 1.000 & .471 & .187 & -.094 & -.168 & $\begin{array}{c}- \\
.102\end{array}$ \\
\hline $\begin{array}{l}\text { Significan } \\
\text { ce( } 1- \\
\text { tailed })(p)\end{array}$ & .412 & .000 & & .174 & .000 & .165 & .491 & .053 & .110 \\
\hline $\begin{array}{l}\text { (C) } \\
\text { Pearson's } \\
\text { coefficien } \\
\text { t (r) }\end{array}$ & .119 & .005 & .322 & .471 & $\begin{array}{c}1.00 \\
0\end{array}$ & .153 & -.192 & -.325 & $\begin{array}{c}- \\
.290\end{array}$ \\
\hline
\end{tabular}




\begin{tabular}{|c|c|c|c|c|c|c|c|c|c|}
\hline $\begin{array}{l}\text { Significan } \\
\text { ce(1- } \\
\text { tailed)(p) }\end{array}$ & .122 & .126 & .174 & & .000 & .024 & .162 & .038 & .141 \\
\hline $\begin{array}{l}\text { (D) } \\
\text { Pearson's } \\
\text { coefficien } \\
\text { t (r) }\end{array}$ & .180 & -.111 & .092 & .187 & .153 & 1.000 & .064 & -.142 & .048 \\
\hline $\begin{array}{l}\text { Significan } \\
\text { ce( } 1- \\
\text { tailed })(p)\end{array}$ & .105 & .481 & .000 & .000 & & .053 & .021 & .000 & .001 \\
\hline $\begin{array}{l}\text { (E) } \\
\text { Pearson's } \\
\text { coefficien } \\
\text { t (r) }\end{array}$ & .035 & .023 & .002 & -.094 & -.192 & .064 & 1.000 & .127 & .027 \\
\hline $\begin{array}{l}\text { Significan } \\
\text { ce }(1- \\
\text { tailed })(p)\end{array}$ & .028 & .120 & .165 & .024 & .053 & & .251 & .067 & .308 \\
\hline $\begin{array}{l}\text { (F) } \\
\text { Pearson's } \\
\text { coefficien } \\
\text { t }(r)\end{array}$ & -.040 & -.062 & -.153 & -.168 & -.325 & -.142 & .127 & 1.000 & .330 \\
\hline $\begin{array}{l}\text { Significan } \\
\text { ce }(1- \\
\text { tailed })(p)\end{array}$ & .358 & .403 & .491 & .162 & .021 & .251 & & .091 & .386 \\
\hline $\begin{array}{l}\text { (G) } \\
\text { Pearson's } \\
\text { coefficien } \\
\text { t (r) }\end{array}$ & -.040 & -.062 & -.153 & -.168 & -.325 & -.142 & .127 & 1.000 & .330 \\
\hline $\begin{array}{l}\text { Significan } \\
\text { ce( } 1 \text { - }\end{array}$ & .337 & .258 & .053 & .038 & .000 & .067 & .091 & & .000 \\
\hline tailed)(p) & & & & & & & & & \\
\hline $\begin{array}{l}(\mathrm{H}) \\
\text { Pearson's } \\
\text { coefficien } \\
t(\mathrm{r})\end{array}$ & -.049 & .092 & -.116 & -.102 & -.290 & -.048 & .027 & .330 & $\begin{array}{c}1.00 \\
0\end{array}$ \\
\hline $\begin{array}{l}\text { Significan } \\
\text { ce( } 1- \\
\text { tailed })(p)\end{array}$ & .304 & .167 & .110 & .141 & .001 & .308 & .386 & .000 & \\
\hline
\end{tabular}


Table 5: Model summary

\begin{tabular}{|l|c|c|c|c|}
\hline Model & R & R Square & Adjusted R Square & $\begin{array}{c}\text { Std. Error of the } \\
\text { Estimate }\end{array}$ \\
\hline 1 & $.381^{\mathrm{a}}$ & .146 & .080 & 2.82793 \\
\hline
\end{tabular}

a. Predictors: (Constant), A,B,C,D,E,F,G,H.

Table 6 documents that the model is fit at $5 \%$ level of significance as $\mathrm{p}<.05$.

Table 6 : Model Fitness (ANOVA $\left.{ }^{a}\right)$

\begin{tabular}{|l|l|c|c|c|c|c|}
\hline \multicolumn{2}{|l|}{ Model } & $\begin{array}{c}\text { Sum of } \\
\text { Squares }\end{array}$ & Df & $\begin{array}{c}\text { Mean } \\
\text { Square }\end{array}$ & F & Sig. \\
\hline \multirow{3}{*}{1} & Regression & 141.654 & 8 & 17.707 & & \multirow{2}{*}{$032^{\mathrm{b}}$} \\
\cline { 2 - 5 } & Residual & 831.709 & 104 & 7.997 & 2.214 &. \\
\cline { 2 - 5 } & Total & 973.363 & 112 & & & \\
\hline
\end{tabular}

a. Dependent Variable: ESS

b. Predictors: (Constant), A, B, C, D, E, F, G, H.

Table 7 represents that there exists a positive association between the sleepiness score (ESS) and the IV factors; average number of calls made/received per day and the expectation of others around to be accessible via phone. This association is statistically significant as $\mathrm{p}<0.05$. Thus, HO1 and HO5 are accepted. Other hypotheses are rejected as the other variables are not positively related to the daytime sleepiness (ESS) since $\mathrm{p}>.05$. Thus, HO2, HO3, HO4, HO6, $\mathrm{HO} 7$ and HO8 are not accepted.

Table 7 : Multiple regression analysis (Coefficients ${ }^{\mathrm{a}}$ )

\begin{tabular}{|c|c|c|c|c|c|}
\hline \multirow[t]{2}{*}{ Model } & \multicolumn{2}{|c|}{$\begin{array}{l}\text { Unstandardized } \\
\text { Coefficients }\end{array}$} & \multirow{2}{*}{$\begin{array}{c}\text { Standardized } \\
\text { Coefficients } \\
\text { Beta } \\
\end{array}$} & \multirow[t]{2}{*}{$\mathrm{T}$} & \multirow[t]{2}{*}{ Sig. } \\
\hline & B & Std. Error & & & \\
\hline (Constant) & 4.748 & 1.439 & & 3.298 & .001 \\
\hline $\begin{array}{l}\text { Average calls } \\
\text { made/received per day }\end{array}$ & .001 & .000 & .339 & 3.410 & .001 \\
\hline $\begin{array}{l}\text { Text messages } \\
\text { made/received per day }\end{array}$ & -.002 & .001 & -.199 & -1.929 & .056 \\
\hline $\begin{array}{l}\text { How often have you } \\
\text { been awakened by your } \\
\text { mobile phone? }\end{array}$ & .171 & .236 & .076 & .727 & .469 \\
\hline
\end{tabular}




\begin{tabular}{|l|l|l|l|l|l|}
\hline 1 & $\begin{array}{l}\text { How often have you } \\
\text { stayed up late than you } \\
\text { wanted because of } \\
\text { mobile? }\end{array}$ & .245 & .241 & .118 & .312 \\
\hline $\begin{array}{l}\text { To what extent are you } \\
\text { expected by those } \\
\text { around to be accessible } \\
\text { via mobile? }\end{array}$ & .659 & .304 & .205 & .032 \\
\hline $\begin{array}{l}\text { accessibility via mobile } \\
\text { phones stressful? }\end{array}$ & .173 & .408 & .040 & .425 & .672 \\
\hline $\begin{array}{l}\text { Do you or someone } \\
\text { around u feels u use d } \\
\text { mobile too much? }\end{array}$ & .309 & .645 & .048 & .478 & .633 \\
\hline $\begin{array}{l}\text { Have u tried but failed, } \\
\text { to cut doen mobile use? }\end{array}$ & -.387 & .564 & -.068 & -.687 & .494 \\
\hline
\end{tabular}

a. Dependent Variable: ESS

Derived Model:

\section{Epworth Sleepiness Scale $=4.748+.001$ (Average calls) +.659 (Accessibility Expectation)}

\section{Results and Findings}

The major findings by the current study documented that daytime sleepiness is students is positively related to the average number of calls made or received per day and the expectation of others to have the student accessible via mobile phones. Hence, higher the number of calls and the stipulated expectation, higher would be the ESS score and eventually, higher daytime sleepiness would be witnessed in the students. The analysis documented that the maximum number of students showed "Higher Normal Daytime Sleepiness" (52.2\%) followed by Lower Normal sleepiness (36.3\%), mild excessive daytime sleepiness $(8.8 \%)$ and the minimum represented moderate excessive sleepiness $(2.7 \%)$. None of them showed secure excessive daytime sleepiness. This implies that majority of the students fall in the category of normal score of daytime sleepiness which would not result in any severe health problems, provided the score doesn't rise over a period of time. The ones belonging to the mild and moderate excessive daytime sleepiness are at comparatively higher risk of maintaining concentration and other health issues (Johns, 2002). Gratefully, none belonged to the category of secure excessive daytime sleepiness or beyond which is considered to be hazardous. As depicted from hypothesis testing, high average number of calls made/received and higher expectation of the known ones of the student to be accessible via mobile could be the statistically significant reasons attribute to the higher sleepiness score.

\section{Conclusion and Sociological implications}

Higher usage of mobile phones for making or receiving calls and being accessible through this disruptive technology is one of the reasons for higher Epworth Sleepiness Scale score in Generation Y. Higher ESS score in turn affects the rhythm of their biological cycle, concentration level, attention span and productivity in regard to the various activities performed during the day. In order to curb this, it is important to have the facts in hand through 
primary research as documented by the current study. Having identified the level of impact these factors related to mobile usage have on millennial daytime sleepiness, measure can be taken to curb them or decline the usage through some well defined measures. A stringent approach can be adopted by parents at home and teachers in the educational institutes to keep a check on excessive usage and discourage it. Another way is a direct interaction with the respondents which reflects upon the sideeffects of such insane usage on their health and move with participative cooperation. It is an important sociological issue being faced by the young generation as never before in our country had any disruptive technology been available so widely and easily on a user-friendly platform.

\section{REFERENCES}

1) Akanferi, Aziale \& Asampana (2014), An empirical study on mobile phone usage among young adults in Ghana: From the viewpoint of university students, International Journal of Computer Applications, 98(5), pp. 15-21, retrieved from : https ://pdfs.semanticscholar.org/65a0/b7924d9c95d ddcb8170a1185e9af69d93e06.pdf?_ga=2.2583256 45.603669821.1517851203-242395719.1517851203

2) Amrit, D. (2004, April 20), Indian youth at the wheel in drive for cultural change, The Observer, New Delhi, pp. 9.

3) Bamzai, K. (2007, February 19), Cover story: home and happy, India Today, retrieved from: http://www.indiatoday.com/itoday/20070219/ cover.com

4) Carter, B., Rees, P., Hale, L., Bhattacharjee, D. \& Paradkar, M.(2016), A meta-analysis of the effect of media devices on sleep outcomes, JAMA Pediatrics, 170(12), pp. 1202-1208, retrieved $\begin{array}{lllll}\mathrm{f} & \mathrm{r} & \mathrm{o} & \mathrm{m}\end{array}$ http://doi.org/10.1001/jamapediatrics.2016.234 1 .

5) Davey, S., \& Davey, A.(2014), Assessment of Smartphone Addiction in Indian Adolescents: A Mixed Method Study by Systematic-review and
Meta-analysis Approach, International Journal of Preventive Medicine, 5(12), pp. 1500-1511.

6) Deepali, A, Shobha, M.V. \& Srinivasa, P. (2015), A study of mobile phone usage on sleep and stress among first year medical students, Research Journal of Pharmaceutical, Biological and Chemical Sciences, 6, pp. 720-723.

7) Gaur, A.S. \& Gaur, S.S. (2012), Statistical Methods for Practice and Research, Sage: Delhi.

8) Gold, J. E., Rauscher, K. J. \& Zhu, M. (2015), A validity study of self-reported daily texting frequency, cell phone characteristics, and texting styles among young adults, BMC Research Notes, $8, \quad$ pp. 120. http:// doi.org/10.1186/s13104-015-1090-3

9) Hale, L., \& Guan, S. (2015), Screen Time and Sleep among School-Aged Children and Adolescents: A Systematic Literature Review, Sleep Medicine Reviews, 21, pp. 50-58, retrieved from: http:/ / doi.org/10.1016/j.smrv.2014.07.007

10) http:/ / epworthsleepinessscale.com/about-theess/

11) Johns, M.W. (1991), A new method of measuring daytime sleepiness: the Epworth sleepiness scale, Sleep, 14, pp. 540-545.

12) Johns, M.W., et al(2002), Validation of a Chinese version of Epworth Sleepiness, Quality of Life Research, 11(8), pp.817-821.

13) Johns, M.W. \& Hocking, B (1997), Daytime Sleepiness and Sleep Habits of Australian Workers, Sleep, 20(10), pp. 844-847.

14) Kawade, T., Kataoka, T., Tsuji, F., Nakade, M., Krejci, M., Noji, T., Takeuchi, H. \& Harada, T. (2017), The relationship between a night usage of mobile phone and sleep habit and the circadian typology of Japanese students aged 18-30 years, Psycholgy,8, pp. 892- 902, retrieved from: https:// doi.org/10.4236/psych.2017.86058

15) Nasirudeen, A.M.A., Adeline, L.L.C., Josephine, K.W.N., Seng, L.L. \& Wenjie, L. (2017), Impact of social media usage on daytime sleepiness: A study in a sample of tertiary students in Singapore, Digital Health, 3, pp. 1-9, retrieved from: $10.1177 / 2055207617699766$

16) Nathan, N. \& Zeitzer, J. (2013), A survey study of 
the association between mobile phone use and daytime sleepiness in California high school students, BMC Public Health, 13, pp. 840, retrieved from: http://doi.org/10.1186/14712458-13-840.

17) Nehra, R., Kate, N., Grover, S., Khehra, N. \& Basu, D. (2012), Journal of postgraduate medical education research, 46(4), pp. 177-182.

18) Patel, A. \& Rathod, H.(2011), Mobile phone usage habits of students commuting from rural areas to nearby town - An exploratory study of Visnagar (Gujarat- India), Global Journal of Management and Business Research, 11(6), pp. 30-38.

19) Sanford, S.D., et al (2006), The influence of age, gender, ethnicity and insomnia on Epworth Sleepiness scale scores: A Normative US population, retrieved from: https:// doi.org/10.1016/j.sleep.2006.01.010

20) Shobha, M.V., Deepali, A \& Srinivasa, P. (2015), A study of mobile phone usage on sleep quality and day time sleepiness, Research Journal of Pharmaceutical, Biological and Chemical Sciences. 6. pp. 1604-1607.

21) Subba, S.H., et al (2013), Ringxiety and the Mobile Phone Usage Pattern among the Students of a Medical College in South India, Journal of Clinical and Diagnostic Research $\square$ : JCDR, 7(2), pp. 205-209, retrieved from: http:// doi.org/10.7860/JCDR/2013/4652.2729

22) Tamura, H., Nishida, T., Tsuji, A. \& Sakakibara, H. (2017), Association between excessive use of mobile phone and insomnia and depression among Japanese Adolescents, International Journal of Environmental Research and Public Health, 14, pp. 701-710, retrieved from: www.mdpi.com/journal/ijerph

23) Troxel, W.M., Hunter, G. \& Scharf, D. (2015), Say "GDNT": Frequency of Adolescent Texting at Night, retrieved from: 10.1016/j.sleh.2015.09.006 